\title{
MARGINAL REGIONS MATHEMATICS TEACHERS' PERCEPTION OF THE USE OF MANIPULATIVE TOOLS
}

\author{
Krisna Satrio Perbowo ${ }^{1}$, Dian Lestari ${ }^{2}$, Syafika Ulfah $^{3}$, Rosida Rakhmawati ${ }^{4}$ \\ ${ }^{1}$ Universitas Muhammadiyah Prof Dr HAMKA, Jl. Tanah Merdeka, Jakarta, Indonesia \\ krisna_satrio@uhamka.ac.id \\ ${ }^{2}$ Universitas Muhammadiyah Prof Dr HAMKA, Jl. Tanah Merdeka, Jakarta, 13830, Indonesia \\ dianlestari81867@gmail.com \\ ${ }^{3}$ Universitas Muhammadiyah Prof Dr HAMKA, Jl. Tanah Merdeka, Jakarta, 13830, Indonesia \\ syafika.ulfah@uhamka.ac.id \\ ${ }^{4}$ Coventry University, Priory St, Coventry, CV1 5FB, United Kingdom \\ muhammadr@uni.coventry.ac.uk
}

\begin{abstract}
Manipulative tool is one of the learning media most likely to be used by teachers, including those in marginal regions. This study aimed to determine the perception of mathematics teachers in marginal regions toward using manipulative tools as learning media. This study used surveys designed with two domains: the use of manipulative tools as learning media and the importance of manipulative tools as learning media. The sample for this study comprised 81 teachers who were either currently teaching or had previously taught at the elementary, middle, and high school levels in marginal regions. This study found that the manipulative tools mostly used by mathematics teachers in marginal regions are objects obtained from the surrounding environment (used cans, paperboard, coins, rulers, stones, and sticks). This study revealed that the mathematics teacher's perception of manipulative tools as learning media and the importance of manipulative tools as learning media are generally in the medium category.
\end{abstract}

\section{ARTICLE INFORMATION}

\section{Keywords}

Perception

Manipulative Tools

Marginal Regions

\section{Article History}

Submitted Jun 23, 2021

Revised Nov 12, 2021

Accepted Nov 27, 2021

Corresponding Author

Krisna Satrio Perbowo,

Departement of Mathematics Education,

Universitas Muhammadiyah Prof Dr HAMKA,

Jl. Tanah Merdeka, Rambutan, Pasar Rebo, Jakarta Timur, Jakarta, 13830, Indonesia.

Email: krisna_satrio@uhamka.ac.id

\section{How to Cite}

Perbowo, K. S., Lestari, D., Ulfah, S., \& Rakhmawati, R. (2021). Marginal Regions Mathematics Teachers' Perception of the Use manipulative tools. Kalamatika: Jurnal Pendidikan Matematika, 6(2), 143-156.

https://doi.org/10.22236/KALAMATIKA.vol6no2.2021pp143-156

\section{$(\mathrm{cc}) \overline{\mathrm{B} Y-\mathrm{SA}}$}

This work is licensed under a Creative 


\section{INTRODUCTION}

Proper education cannot be accessed by some people living in marginal regions because human resources and governance have not fully contributed to developing the regions (Chaerul et al., 2015). Communities in marginal regions have not been able to access adequate infrastructure, health services, and education (Pateman, 2011) due to the numerous inhibiting factors, such as remote location, which hamper the provision of educational support facilities, for example, learning media. Various limitations in marginal regions affect both students' academic abilities, and patterns of learning (Wolf et al., 2017) involve the selection of learning media.

Learning media is also used as learning resources (Saputra et al., 2018), providing many benefits, particularly in abstract mathematics learning. Sudjana \& Rivai in (Arsyad, 2011) suggested several benefits of learning media in the learning process: making teaching more interesting, fostering learning motivation, clarifying the contents of teaching materials, making teaching methods more varied, and increasing student involvement. Media used for learning math include manipulative tools, and ICT can encourage students to participate more and be more engaged in learning (Nomleni \& Manu, 2018).

Several studies have found no relationship between the increase in the use of ICT media and student achievement. The use of ICT in learning has not shown a satisfying impact (Kirkup \& Kirkwood, 2005; Wopereis et al., 2005). It was found that there was a negative, significant and consistent relationship between the use of ICT and some aspects of student achievement (Leuven et al., 2007; Youssef \& Dahmani, 2008). As commonly known, students tend to use ICT in their free time for leisure than for studying. Moreover, the ICT-based learning media is also difficult to apply in marginal regions because of the many obstacles such as lack of the necessary equipment, shortage of electricity, difficulty in obtaining internet connection, and low quality of human resources (Pelgrum, 2001))

An alternative learning media is a manipulative tool that can be defined as a set of concrete objects designed, created, and arranged to help students understand or develop learning concepts or principles (Anas, 2014). These tools are convenient to make and use. Hence, they have a high practicality value in learning mathematics in various areas (Subarinah et al., 2019). It can be a decisive component of the effectiveness of learning since it can transform abstract teaching materials into concrete and realistic, as the main function is to reduce the abstraction 
of a concept. The research conducted by Wieman (Hapsoro \& Susanto, 2012) found that manipulative tools can transform weak memory into understanding and appreciation. Meanwhile, Rusmawati (2017) and Dahniar et al., (2010) found that manipulative tools in mathematics can improve students' learning outcomes. This shows that the use of manipulative tools can improve the quality of student learning.

On the other hand, many mathematics teachers rarely use manipulative tools in the learning process (Karma \& Rahmi, 2018), which is likely contributed by the teacher's lack of ability to design manipulative teaching tools (Fadillah et al., 2018). Students learn more conventionally or through direct explanation with lecture methods, and students tend to memorize mathematical concepts or procedures. As a result, students learn mathematics in ways that are less meaningful and boring. This certainly affects students' mathematics learning outcomes.

Teachers' perceptions of ICT use in learning have been widely studied (Dong, 2018; Kennah, 2016; Olivares \& Castillo, 2018; Suliman, 2017), while only a few researchers paid attention to the teacher's views on the use of manipulative tools. All limitations experienced by mathematics teachers in marginal regions affect the perception of using manipulative tools in learning mathematics. This encourages a need to examine the perception of mathematics teachers in marginal regions toward using manipulative tools as learning media. This is noteworthy as a basis for developing mathematics learning media in marginal regions.

\section{METHOD}

Research conducted by researchers included descriptive quantitative research with a survey method by distributing questionnaires about the perception of teachers in the marginal regions on the use of manipulative tools. The instrument used was adapted from (Suliman, 2017), consisted of two domains: the use of manipulative tools as learning media (17 statement items) and the importance of using manipulative tools as learning media (26 statement items). It was distributed online by Google forms. Questionnaire data were analyzed using the Rasch model with the Winstep application (Sumintono \& Widhiarso, 2014). Respondents' responses are in the form of scale or ranking, and each domain has a different scale, as seen in Table 1. 
Table 1 . Item logit category

\begin{tabular}{cccc}
\hline \multicolumn{2}{c}{ Domain interpretation 1: } & \multicolumn{2}{c}{ Domain interpretation 2: } \\
\multicolumn{2}{c}{$\begin{array}{c}\text { The usefulness of manipulative tools } \\
\text { Mean Range }\end{array}$} & Decision & The importance of using manipulative tools \\
\hline$x \leq 0.69$ & Always & Mean Range & Decision \\
$-0.69<x \leq-0.23$ & Often & $-1.07<-1.07$ & Very important \\
$-0.23<x \leq 0.23$ & Sometimes & $-0.36<x \leq 0.36$ & Important \\
$0.23 \leq x \leq 0.69$ & Rarely & $0.36 \leq x \leq 1.07$ & Rather important \\
$0.69<x$ & Never & $1.07<x$ & Rarely \\
\hline
\end{tabular}

The sampling technique used was convenience sampling due to the difficulties in reaching the potential respondents spread across regions in Indonesia. The sample in this study consisted of 81 mathematics teachers in the marginal regions (Perpres, 2015), ranging from elementary (D), junior high (P), to high school (A) spread from western Indonesia (W) to eastern Indonesia (E). The detailed number of respondents in each region is in Table 2. Locations within western Indonesia included the island of Sumatra, Java, Kalimantan, and Bali Province. Those in eastern Indonesia included Sulawesi Island, Maluku Province, West Nusa Tenggara Province, East Nusa Tenggara Province, and Papua Island.

Table 2. Grouping data based on geographical location and level of education

\begin{tabular}{lrrrrr}
\multicolumn{1}{c}{$\begin{array}{c}\text { Geographical } \\
\text { location }\end{array}$} & D & \multicolumn{2}{c}{ Level } & A & \multicolumn{2}{c}{ Total } \\
\hline West & 29 & 15 & 6 & 50 \\
East & 4 & 21 & 6 & 31 \\
\hline Total & 33 & 36 & 12 & 81 \\
\hline
\end{tabular}

\section{RESULT AND DISCUSSION}

\section{Data on the Type of Manipulative Tools Used}

The type of smanipulative tools used in mathematics learning activities in the marginal area based on geographical location is presented in Table 3. It shows that nature-found tools are frequently used in western Indonesia (28 people) compared to Eastern Indonesia, with only 11 people or $48.15 \%$ users. The use of the tools found in natural environments is one solution that can be applied by educators who teach in the marginal area, where school facilities and infrastructure are inadequate (Crismono, 2017).

Table 3. Media Usage Types of Manipulative tools based on geographical location

\begin{tabular}{|c|c|c|c|c|}
\hline \multirow{2}{*}{ Manipulative tools } & \multicolumn{2}{|c|}{ Geographical location } & \multirow{2}{*}{ Total } & \multirow{2}{*}{ Percentage } \\
\hline & West & East & & \\
\hline Obtained from nature around & 28 & 11 & 39 & $48.15 \%$ \\
\hline Two-dimensional figure & 0 & 4 & 4 & $4.94 \%$ \\
\hline Geometry & 15 & 10 & 25 & $30.86 \%$ \\
\hline Abacus and tangram & 0 & 1 & 1 & $1.23 \%$ \\
\hline Term and arc & 2 & 1 & 3 & $3.70 \%$ \\
\hline Math KIT & 3 & 0 & 3 & $3.70 \%$ \\
\hline Sempoa & 1 & 0 & 1 & $1.23 \%$ \\
\hline None & 0 & 4 & 4 & $4.94 \%$ \\
\hline
\end{tabular}




\begin{tabular}{|c|c|c|c|c|}
\hline \multirow{2}{*}{ Manipulative tools } & \multicolumn{2}{|c|}{ Geographical location } & \multirow{2}{*}{ Total } & \multirow{2}{*}{ Percentage } \\
\hline & West & East & & \\
\hline Generic Kit by Diknas & 1 & 0 & 1 & $1.23 \%$ \\
\hline Total & 50 & 31 & 81 & $100.00 \%$ \\
\hline
\end{tabular}

The types of manipulative tools as teaching media in learning mathematics based on the educational level in the marginal regions are displayed in Table 4. It shows that manipulative tools are widely used in mathematics classes at elementary schools, with 23 people using tools from nature. At the junior high school level, manipulative tools are also commonly used by 17 out of 25 users. Meanwhile, at the high school level, it was found that some mathematics teachers use natural tools in their lessons while others prefer to carry out lessons without manipulative tools.

Table 4. Types of media usage of manipulative tools based on geographic location and level of education

\begin{tabular}{lccccccc}
\multicolumn{1}{c}{ Manipulative tools } & \multicolumn{3}{c}{ West } & \multicolumn{2}{c}{ East } & \multicolumn{2}{c}{ Total } \\
& $\mathrm{D}$ & $\mathrm{P}$ & $\mathrm{A}$ & $\mathrm{D}$ & $\mathrm{P}$ & $\mathrm{A}$ & 39 \\
Obtained from nature around & 21 & 4 & 3 & 2 & 9 & 0 & 4 \\
Two-dimensional figure & 0 & 0 & 0 & 0 & 4 & 0 & 25 \\
Geometry & 4 & 10 & 1 & 0 & 7 & 3 & 1 \\
Dekak-dekak and tangram & 0 & 0 & 0 & 1 & 0 & 0 & 3 \\
Term and arc & 0 & 0 & 2 & 0 & 1 & 0 & 3 \\
Math KIT & 3 & 0 & 0 & 0 & 0 & 0 & 1 \\
Sempoa & 1 & 0 & 0 & 0 & 0 & 0 & 4 \\
There is no & 0 & 0 & 0 & 1 & 0 & 3 & 1 \\
The service provided & 0 & 1 & 0 & 0 & 0 & 0 & 6 \\
\hline \multicolumn{1}{c}{ Total } & 29 & 15 & 6 & 4 & 21 & 6 & 81 \\
\hline
\end{tabular}

\section{Data usage of manipulative tools as Learning Media}

The questionnaire consisted of 17 items regarding the use of manipulative tools as learning media. Eighty-one mathematics teachers in marginal regions completed the questionnaire, ranging from elementary (D), junior (P), and high school (A) levels spread from western Indonesia (W) to Eastern Indonesia (E). The variable map in Table 5 shows that the items that were most difficult to agree upon by respondents were items 10 and 12. Meanwhile, items that were strongly approved were item number 15. 


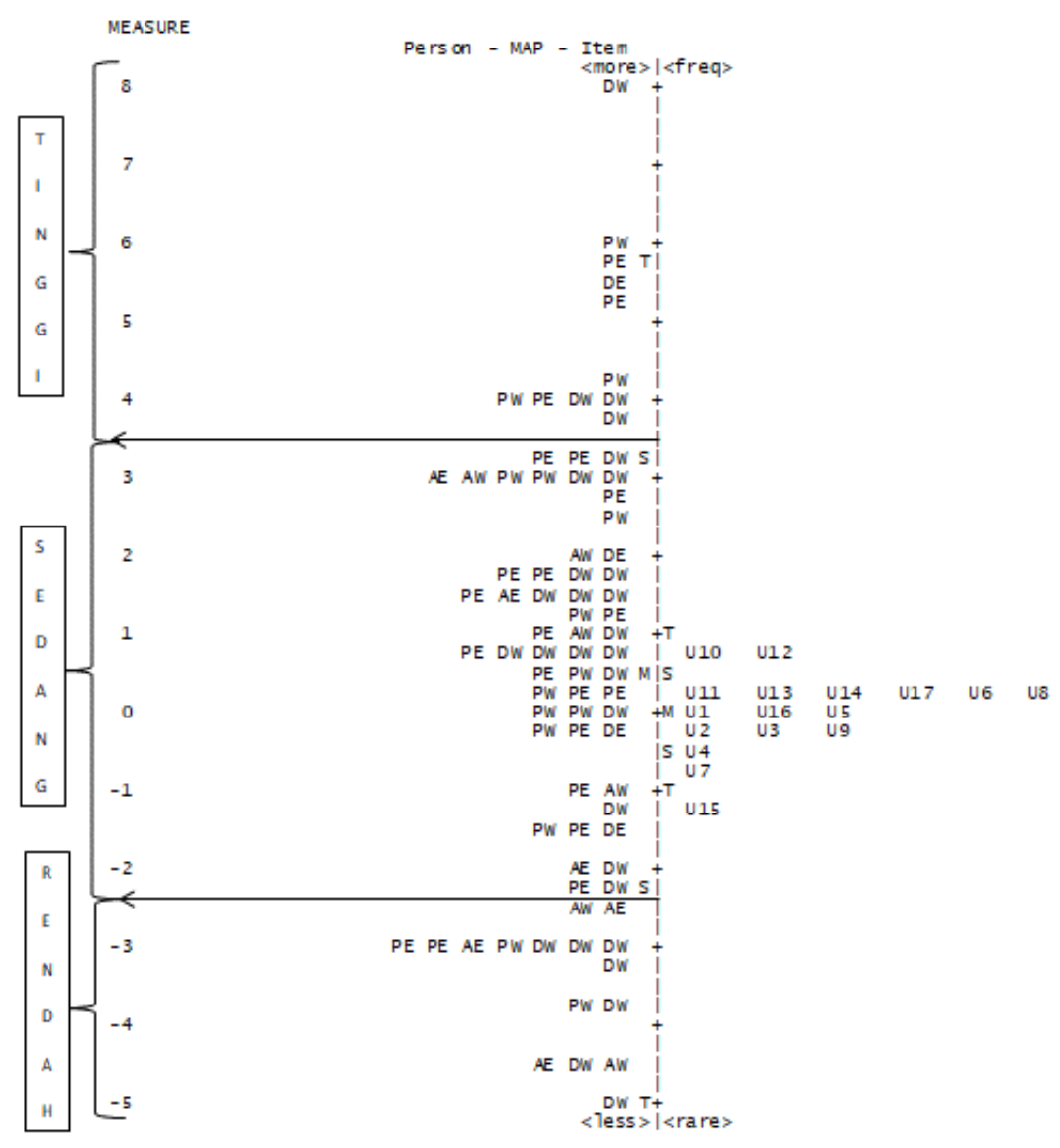

Figure 1. Variable maps of the frequency of use of manipulative tools as a learning medium

Meanwhile, table 5 shows the logit standard deviation values according to the item logit category of respondents' responses in table 1. As shown in Table 5, there are four items in the category of "rarely" (items 8, 10, 14, and 17), whereas one item (item 15) falls into the "always" category. Moreover, it can be seen that 12 items are categorized as "rarely" and "sometimes," and four items are categorized as "always" and "often." In addition to that, 1 item is categorized as "never." Table 5 is based on the standard deviation of the logit results of processing with Rasch modeling to scale the respondents' responses in table 1.

Table 5. Domain 1: frequency of use of manipulative tools as a learning medium

\begin{tabular}{clrr}
\hline No & \multicolumn{1}{c}{ Item } & P. SD & $\begin{array}{r}\text { Usage } \\
\text { level }\end{array}$ \\
\hline 1. & I use manipulative tools as a method of learning mathematics & 0.10 & Sometimes \\
2. & I encourage students to learn mathematics using manipulative tools & -0.15 & Sometimes \\
3. & I tell students media manipulative tools that are useful & -0.27 & Often \\
4. & I monitor the academic improvement of students after the use of manipulative tools & -0.53 & Often \\
5. & I implemented the concept of cooperative learning by using manipulative tools & -0.02 & Sometimes \\
6. & I implemented the concept of cooperative learning by using manipulative tools & 0.19 & Sometimes \\
7. & I provide opportunities for students to work together in learning through the use of manipulative & -0.66 & Often \\
& tools. & &
\end{tabular}




\begin{tabular}{clrr}
\hline \multirow{2}{*}{ No } & \multicolumn{1}{c}{ Item } & P. SD & $\begin{array}{r}\text { Usage } \\
\text { level }\end{array}$ \\
\hline 8. & I overcome the students' problems that arise when learning to use manipulative tools & 0.35 & Rarely \\
9. & I invite some parts of mathematics material using manipulative tools & -0.15 & Sometimes \\
10. & I provide additional activities for students using manipulative tools. & 0.64 & Rarely \\
11. & I assign in groups to discuss and solve problems to use manipulative tools & 0.15 & Sometimes \\
12. & I prepare quizzes for students and work on them using manipulative tools. & 0.76 & Never \\
13. & I design learning using manipulative tools. & 0.23 & Sometimes \\
14. & I train students to discuss and explore mathematical concepts using manipulative tools. & 0.31 & Rarely \\
15. & The manipulative tools give me another way to teach mathematics & -1.15 & Always \\
16. & I allow students to experiment using manipulative tools & -0.11 & Sometimes \\
17. & I exchange strategies in teaching to use manipulative tools with colleagues or colleagues & 0.31 & Rarely \\
\hline
\end{tabular}

The perception of mathematics teachers in marginal regions on the use of manipulative tools in figure 1 shows the distribution of demographics based on their level of education, geographical location, and geographical location. The distribution of data based on education levels shows that those with high perceptions are found at the junior high school level of 54.55\% (11 people). Meanwhile, for the medium perception, the highest is seen in junior high school level (48.15\% or 54 people). Moreover, those with low perception are mainly at the elementary school level (43.75\% or 16 people), as shown in Table 6.

Table 6. Perception of the use of manipulative tools based on education

\begin{tabular}{|c|c|c|c|c|c|c|c|c|}
\hline \multirow{2}{*}{ Category } & \multicolumn{6}{|c|}{ Level } & \multirow{2}{*}{\multicolumn{2}{|c|}{ Total }} \\
\hline & \multicolumn{2}{|c|}{ D } & \multicolumn{2}{|c|}{$\mathrm{P}$} & \multicolumn{2}{|c|}{ A } & & \\
\hline High & 5 & $45.45 \%$ & 6 & $54.55 \%$ & 0 & $0 \%$ & 11 & $13.58 \%$ \\
\hline Moderate & 21 & $38.89 \%$ & 26 & $48.15 \%$ & 7 & $12.96 \%$ & 54 & $66.67 \%$ \\
\hline Low & 7 & $43.75 \%$ & 4 & $25.00 \%$ & 5 & $31.25 \%$ & 16 & $19.75 \%$ \\
\hline Total & \multicolumn{2}{|c|}{33} & \multicolumn{2}{|c|}{36} & \multicolumn{2}{|c|}{12} & \multicolumn{2}{|c|}{81} \\
\hline
\end{tabular}

The perception of mathematics teachers in the marginal regions towards using manipulative tools on teaching based on geographical location was also identified based on education. In western Indonesia, the high perception was $63.64 \%$ (11 people). Meanwhile, those with medium perception were $59.26 \%$ (54 people), and $68.75 \%$ (16 people) was in a low category, as presented in Table 7

Table 7. Perception uses manipulative tools by Geographic Location

\begin{tabular}{lrrrrrr}
\hline \multirow{2}{*}{ Category } & \multicolumn{3}{c}{ Geographical location } \\
& \multicolumn{2}{c}{ East } & \multicolumn{2}{c}{ West } & \multicolumn{3}{c}{ Total } \\
\hline High & 4 & $36.36 \%$ & 7 & $63.64 \%$ & 11 & $13.58 \%$ \\
Moderate & 22 & $40.74 \%$ & 32 & $59.26 \%$ & 54 & $66.67 \%$ \\
Low & 5 & $31.25 \%$ & 11 & $68.75 \%$ & 16 & $19.75 \%$ \\
\hline \multicolumn{1}{c}{ Total } & & 31 & & 50 & & 81 \\
\hline
\end{tabular}

Geographically, mathematics teachers' perception in the marginal regions on using manipulative tools can be seen in Table 8. High perceptions were found in elementary schools in western Indonesia by $36.36 \%$ (11 people). Referring to elementary school teachers, their perceptions in Western Indonesia reached $33.33 \%$ out of 54 people is moderate. The low 
perception was indicated at the elementary school level in western Indonesia (43.75\% or 16 people).

Table 8. Perception of the use of manipulative tools based on levels of education and location

\begin{tabular}{|c|c|c|c|c|c|c|c|c|c|c|c|c|c|c|}
\hline \multirow{2}{*}{ Category } & \multicolumn{4}{|c|}{$\mathrm{D}$} & \multicolumn{4}{|c|}{$\mathrm{P}$} & \multicolumn{4}{|c|}{$\mathrm{A}$} & \multirow{2}{*}{\multicolumn{2}{|c|}{ Total }} \\
\hline & & East & & West & & East & & West & & East & & West & & \\
\hline High & 1 & $9.09 \%$ & 4 & $36.36 \%$ & 3 & $27.27 \%$ & 3 & $27.27 \%$ & 0 & $0.0 \%$ & 0 & $0.00 \%$ & 11 & $13.58 \%$ \\
\hline Moderate & 3 & $5.56 \%$ & 18 & $33.33 \%$ & 16 & $29.63 \%$ & 10 & $18.52 \%$ & 3 & $5.6 \%$ & 4 & $7.41 \%$ & 54 & $66.67 \%$ \\
\hline Low & 0 & $0.00 \%$ & 7 & $43.75 \%$ & 2 & $12.50 \%$ & 2 & $12.50 \%$ & 3 & $18.8 \%$ & 2 & $12.50 \%$ & 16 & $19.75 \%$ \\
\hline Total & & 4 & & 29 & & 21 & & 15 & & 6 & & 6 & & 81 \\
\hline
\end{tabular}

\section{Data on the Importance of Using Manipulative Tools as Learning Media}

Table 9 presents data consisting of 26 statement items and 81 respondents. Respondents in this study are mathematics teachers who teach in the marginal regions starting from elementary school (D), junior high school (P), and high school (A), scattered from western Indonesia (W) to eastern Indonesia (E). Based on this table, it can be concluded that the items that were the most difficult to be agreed upon by respondents were items 16. Meanwhile, items that were highly agreed were items 3 and 8 . 


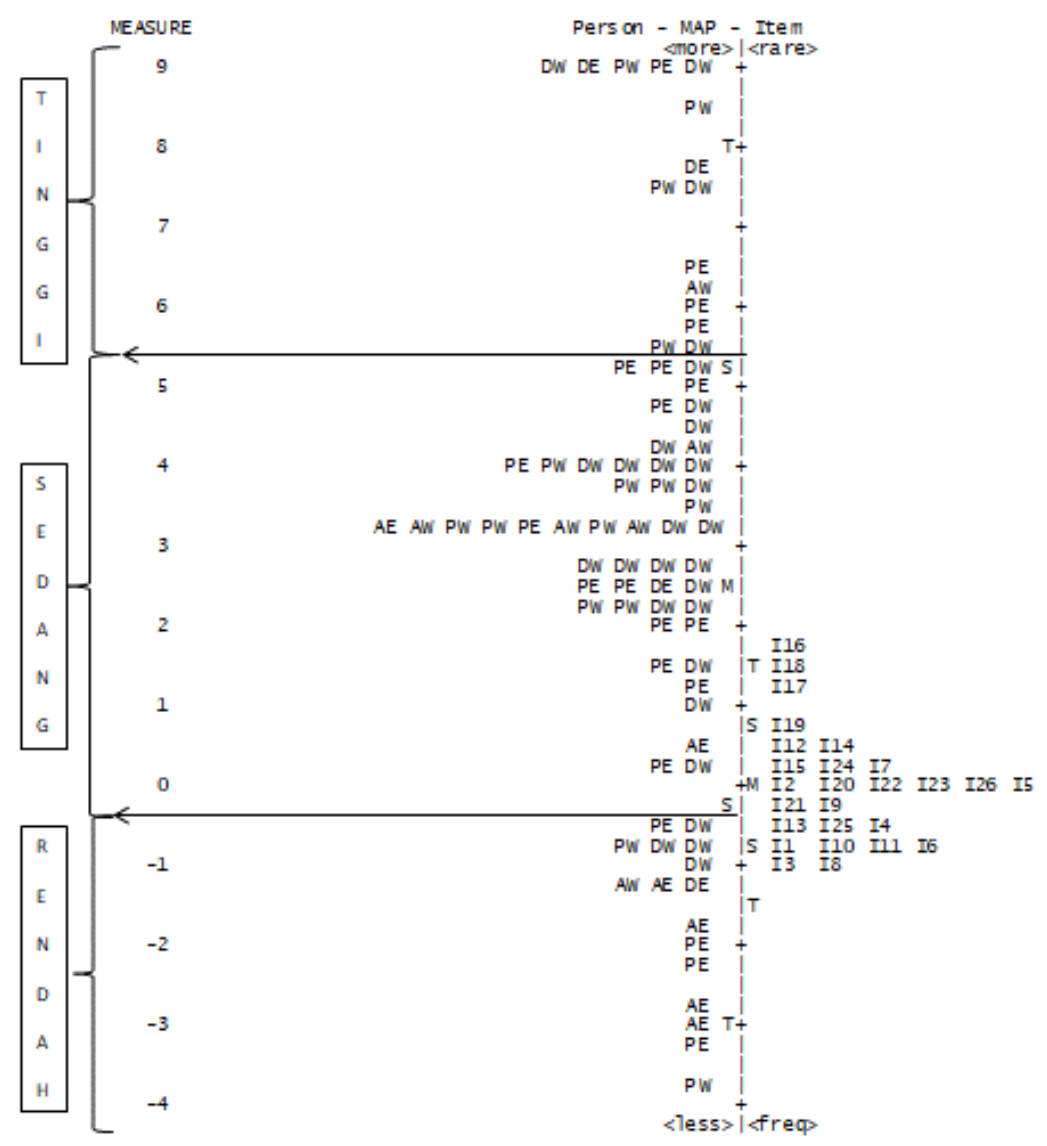

Figure 2. Variable maps the importance of using manipulative tools as learning media

Table 9 shows the results of Rasch modeling (Figure 2) that the scale of respondents' responses. Table 9 indicates three items of "not important" level of use in number $(16,17$, and 18). It can be concluded that giving additional tasks using manipulative tools, assigning group discussions and solving problems with manipulative tools, and assisting teachers in preparing quizzes and then working on them using manipulative tools are not considered of utmost importance for mathematics teachers in the marginal regions. Meanwhile, many responded "very important" to item 3. It can be concluded that mathematics teachers in the marginal regions agreed that media tools could encourage students to actively work in groups.

Table 9. Domain 2: the importance of using manipulative tools as learning media

\begin{tabular}{llrr}
\hline No & \multicolumn{1}{c}{ Item } & P.SD & Usage level \\
\hline 1. & I use manipulative tools in teaching mathematics & -0.67 & Important \\
2. & I encourage students to actively use manipulative tools more than others & 0.11 & Rather important \\
3. & Media manipulative tools encourage students to actively work in groups & -1.10 & Very important \\
4. & I tell students media mathematics learning manipulative tools that are useful & -0.55 & Important \\
5. & Some students develop because they use manipulative tools & -0.07 & Rather important \\
6. & Media manipulative tools are important for students to improve learning outcomes. & -0.74 & Important \\
7. & I encourage students to look for inspiration when they use manipulative tools & 0.35 & Rather important \\
8. & The use of manipulative tools media to make learning interesting & -0.98 & Important \\
\hline
\end{tabular}




\begin{tabular}{|c|c|c|c|}
\hline No & Item & P.SD & Usage level \\
\hline 9. & The use of manipulative tools builds student collaboration and student ability. & -0.13 & Rather important \\
\hline 10. & $\begin{array}{l}\text { Media manipulative tools facilitate the delivery of mathematics learning material to } \\
\text { students }\end{array}$ & -0.80 & Important \\
\hline 11. & Media manipulative tools help me convey information & -0.86 & Important \\
\hline 12. & $\begin{array}{l}\text { Media manipulative tools help in characterizing each student's character or } \\
\text { differences }\end{array}$ & 0.41 & Rarely \\
\hline 13. & Media manipulative tools allow students to work together in learning. & -0.49 & Important \\
\hline 14. & $\begin{array}{l}\text { Media manipulative tools give me the opportunity for students' problems related to } \\
\text { learning mathematics. }\end{array}$ & 0.47 & Rarely \\
\hline 15. & I teach some material using manipulative tools. & 0.29 & Rather important \\
\hline 16. & I gave an additional assignment using manipulative tools. & 1. 66 & Never \\
\hline 17. & I assign in groups to discuss and solve problems to use manipulative tools & 1.19 & Never \\
\hline 18. & Media aids help me prepare a quiz and work on them using manipulative tools. & 1. 51 & Never \\
\hline 19. & I design mathematical material using manipulative tools & 0.86 & Rarely \\
\hline 20. & The use of manipulative tools media helps students increase self-confidence & -0.07 & Rather important \\
\hline 21. & Using manipulative tools provides an important experience for students & -0.19 & Rather important \\
\hline 22. & $\begin{array}{l}\text { The use of manipulative tools media can equip students with the abilities to discuss } \\
\text { and argue }\end{array}$ & 0.11 & Rather important \\
\hline 23. & Media manipulative tools give students the ability to study independently & -0.01 & Rather important \\
\hline 24. & $\begin{array}{l}\text { Media manipulative tools help in bringing up variations in methods of teaching } \\
\text { mathematics }\end{array}$ & -0.17 & Rather important \\
\hline 25. & Media manipulative tools encourage students to learn. & -0.49 & Important \\
\hline 26. & Media manipulative tools help students to acquire social abilities & -0.01 & Rather important \\
\hline
\end{tabular}

The perception of mathematics teachers in the marginal regions on the importance of using manipulative tools in Figure 2 shows the distribution of demographics based on education level and geographical location. The distribution of data based on education levels shows that those who have a high perception are found in junior high school levels (53.33\% or 15 people). The medium perception is mostly in elementary and junior high schools, with the same percentage (44.00\% or 50 people). Meanwhile, low perception is in junior high school level (37.50\% or 16 people), as shown in Table 10.

Table 10. Perception of the importance of manipulative tools based on education levels

\begin{tabular}{|c|c|c|c|c|c|c|c|c|}
\hline \multirow{2}{*}{ Category } & \multicolumn{6}{|c|}{ Educational level } & \multirow{2}{*}{\multicolumn{2}{|c|}{ TOTAL }} \\
\hline & & & & & & & & \\
\hline High & 6 & $40.00 \%$ & 8 & $53.33 \%$ & 1 & $6.67 \%$ & 15 & $18.52 \%$ \\
\hline Moderate & 22 & $44.00 \%$ & 22 & $44.00 \%$ & 6 & $12.00 \%$ & 50 & $61.73 \%$ \\
\hline Low & 5 & $31.25 \%$ & 6 & $37.50 \%$ & 5 & $31.25 \%$ & 16 & $19.75 \%$ \\
\hline Total & & 33 & & 36 & & 12 & & 81 \\
\hline
\end{tabular}

Table 11 presents the perception of mathematics teachers in the marginal regions on the use of manipulative tools based on geographical location. Those with high perception are found in western Indonesia (60.00\% or 15 people). Meanwhile, those with moderate perception are in western Indonesia (68.00\% or 50 people), while the low perception was mostly found in Eastern Indonesia ( $56.25 \%$ or 16 people).

Table 11. Perception of the importance of manipulative tools based on geographic location Category Geographical location Total 


\begin{tabular}{lrrrrrr}
\multicolumn{2}{c}{ East } & \multicolumn{2}{c}{ West } \\
\hline High & 6 & $40.00 \%$ & 9 & $60.00 \%$ & 15 & $18.52 \%$ \\
Moderate & 16 & $32.00 \%$ & 34 & $68.00 \%$ & 50 & $61.73 \%$ \\
Low & 9 & $56.25 \%$ & 7 & $43.75 \%$ & 16 & $19.75 \%$ \\
\hline Total & \multicolumn{7}{r}{} & 31 & 50 & & 81 \\
\hline
\end{tabular}

Table 12 illustrates the perception of mathematics teachers in the marginal region on the importance of manipulative tools based on their educational level and geographical location. It illustrates that high perceptions are found in elementary and junior high schools in western Indonesia ( $26.67 \%$ or 15 people). Pointing to the perception by elementary school teachers, moderate level in Western Indonesia approximately $42.00 \%$ out of 50 people. Meanwhile, the low perception is spread in all levels with the same percentage ( $25.00 \%$ or 16 people).

Table 12. Perception of the importance of manipulative tools based on levels of education and geographical location

\begin{tabular}{|c|c|c|c|c|c|c|c|c|c|c|c|c|c|c|}
\hline \multirow{2}{*}{ Category } & \multicolumn{4}{|c|}{ D } & \multicolumn{4}{|c|}{$\mathrm{P}$} & \multicolumn{4}{|c|}{$\mathrm{A}$} & \multirow{2}{*}{\multicolumn{2}{|c|}{ Total }} \\
\hline & \multicolumn{2}{|c|}{ East } & \multicolumn{2}{|c|}{ West } & \multicolumn{2}{|c|}{ East } & \multicolumn{2}{|c|}{ West } & \multicolumn{2}{|c|}{ East } & \multicolumn{2}{|c|}{ West } & & \\
\hline High & 2 & $13.33 \%$ & 4 & $26.67 \%$ & 4 & $26.67 \%$ & 4 & $26.67 \%$ & 0 & $0.00 \%$ & 1 & $6.67 \%$ & 15 & $18.52 \%$ \\
\hline Moderate & 1 & $2.00 \%$ & 21 & $42.00 \%$ & 13 & $26.00 \%$ & 9 & $18.00 \%$ & 2 & $4.00 \%$ & 4 & $8.00 \%$ & 50 & $61.73 \%$ \\
\hline Low & 1 & $6.25 \%$ & 4 & $25.00 \%$ & 4 & $25.00 \%$ & 2 & $12.50 \%$ & 4 & $25.00 \%$ & 1 & $6.25 \%$ & 16 & $19.75 \%$ \\
\hline Total & & 4 & & 29 & & 21 & & 15 & & 6 & & 6 & & 81 \\
\hline
\end{tabular}

The results above show that the types of manipulative tools widely used in the marginal regions are those from the surrounding environment (48.15\%), such as tins, papers, stones, sticks, wall clocks, and others.

The perception of mathematics teachers in marginal regions on using manipulative tools is categorized as "medium." Most teachers in the regions consider using manipulative tools (66.67\% or 54 people) is a norm, widely spread at western Indonesia's junior high school level. Meanwhile, the perception of mathematics teachers in marginal regions on the importance of using manipulative tools is categorized as moderate. Most teachers in the regions consider it normal to the importance of manipulative tools (61.73\% or 50 people) which is widely spread at the elementary level in western Indonesia. The data shows that the perception of mathematics teachers in disadvantaged areas towards the use of manipulative tools was in the moderate category; that is, most teachers in marginal regions considered the role of manipulative tools as nothing special in mathematics learning.

The results showed that mathematics teachers in the marginal regions perception towards the use of teaching aids as learning media had a moderate perception. Respondents mostly use the natural surroundings as a learning media in the regions due to conditions in disadvantaged areas which have many limitations. Small number of mathematics teachers in marginal regions 
have implemented manipulatives tools in mathematics learning.

\section{CONCLUSION}

Based on the findings of this study, it can be concluded that not all marginal region teachers use manipulative tools in the mathematics classroom. The manipulative tools used in marginal regions are mainly obtained from nature or school environments. Mathematics teachers' perception in the marginal regions on both domains 'the use of manipulatives' and 'the importance of the use of manipulatives' is categorized as moderate level. Dominantly, elementary mathematics teachers have a medium level of perception in both west and east Indonesia region compared to primary and senior high school teachers.

\section{ACKNOWLEDGMENTS}

This study was funded by Lembaga Penelitian Universitas Muhammadiyah Prof Dr HAMKA project Internal Research No.161/F.03.07/2019. We would like to thank Sue JohnstonWilder, Ph.D., for her support and precious thought for this article and mathematics teachers in 3T, especially participants of PPG Dasus 2018, for their participation and contributions during the research.

\section{REFERENCES}

Anas, M. (2014). Alat Peraga dan Media Pembelajaran. Muhammad Anas. https://books.google.co.uk/books?id=nSgaCgAAQBAJ

Arsyad, A. (2011). Media Pembelajaran. Raja grafindo Persada.

Chaerul, M., Aisyah, S., \& A, I. U. (2015). Implikasi Corporate Social Responsibility (CSR) Melaui Entrepreneur School Di Daerah Tertinggal Berbasis $3 E$ (Education, Entrepreneurship, Environment) Menuju Millennium Development Goals (MDGS) 2015. 1, 31-41.

Crismono, P. C. (2017). Penggunaan Media Dan Sumber Belajar dari Alam Sekitar Dalam Pembelajaran Matematika. Jurnal Gammath, 2(2), 72-77.

Dahniar, Murdiana, I. N., \& Sukayasa. (2010). Penggunaan Alat Peraga Untuk Meningkatkan Hasil Belajar Siwa Kelas 1 SD Negeri 6 Tolitoli dalam Menyelesaikan Soal Cerita Tentang Penjumlahan Dan Pengurangan. Jurnal Kreatif Tadulako Online, 4(3), 165- 
177.

Dong, C. (2018). Preschool Teachers' Perceptions and Pedagogical Practices: Young Children's Use of ICT. Early Child Development and Care, 188(6), 635-640. https://doi.org/10.1080/03004430.2016.1226293

Fadillah, S., Wahyudi, \& Nurhayati. (2018). Pemanfaatan Alat Peraga Dalam Pembelajaran Matematika dan IPA Bagi Guru SD/SMP di Desa Tanjung Saleh. 2(1), 95-103.

Hapsoro, C. A., \& Susanto, H. (2012). Penerapan Pembelajaran Problem Based Instruction Berbantuan Alat Peraga pada Materi Cahaya di SMP. Jurnal Pendidikan Fisika Indonesia, 8(1), 28-32.

Karma, R., \& Rahmi, N. (2018). Pembuatan Media Pembelajaran Inovatif Berbasis IPTEK bagi Guru SD Terpencil di Kecamatan Sabbangparu. 2(2), 90-94.

Kennah, M. R. (2016). The Use of ICT in the Teaching and Learning Process in Secondary Schools: A Case Study of Two Cameroonian schools (Issue August). University of Jyväskylä.

Kirkup, G., \& Kirkwood, A. (2005). Information and Communications Technologies (ICT) in Higher Education Teaching - A Tale of Gradualism Rather Than Revolution. Learning, Media \& Technology, 30(2), 185-199. https://doi.org/10.1080/17439880500093810

Leuven, E., Lindahl, M., Oosterbeek, H., \& Webbink, D. (2007). The Effect of Extra Funding for Disadvantaged Pupils on Achievement. Review of Economics and Statistics, 89(4), 721-736. https://doi.org/10.1162/rest.89.4.721

Nomleni, F. T., \& Manu, T. S. N. (2018). Pengembangan Media Audio Visual dan Alat Peraga dalam Meningkatkan Pemahaman Konsep dan Pemecahan Masalah. Scholaria: Jurnal Pendidikan Dan Kebudayaan, 8(3), 219-230. https://doi.org/10.24246/j.js.2018.v8.i3.p219-230

Olivares, D. D., \& Castillo, R. R. (2018). ICT in the Classroom : Primary Education Student Teachers' Perceptions of The Interactive Whiteboard During The Teaching Practicum. Education and Information Technologies, 23(6), 2309-2321. https://doi.org/10.1007/s10639-018-9716-4 
Pateman, T. (2011). Rural and Urban Areas: Comparing Lives Using Rural/Urban Classifications. Regional Trends, 43(1), 11-86. https://doi.org/10.1057/rt.2011.2

Pelgrum, W. J. (2001). Obstacles to The Integration of ICT in Education: Result From Worldwide Educational Assessment. Computers and Education, 37(2), 163-178.

Perpres. (2015). Lampiran Peraturan Presiden Nomor 131 Tahun 2015 Tentang Penetapan Daerah Tertinggal Tahun 2015-2019.

Rusmawati. (2017). Penggunaan Alat Peraga Langsung Pada Pembelajaran Matematika Dengan Materi Pecahan Sederhana Untuk Meningkatkan Hasil Belajar Siswa. Jurnal Ilmu Pendidikan Sosial, Sains, Dan Humaniora, 3(2), 307-314.

Saputra, M., Abidin, T. F., Ansari, B. I., \& Hidayat, M. (2018). The Feasibility of An AndroidBased Pocketbook as Mathematics Learning Media in Senior High School. Journal of Physics: Conference Series, 1088. https://doi.org/10.1088/1742-6596/1088/1/012056

Subarinah, S., Sripatmi, S., Prayitno, S., \& Kurniawan, E. (2019). Pelatihan Pembuatan dan Penggunaan Alat Peraga Matematika pada Guru-Guru SDN 13 Ampenan. Jurnal Pendidikan Dan Pengabdian Masyarakat, 2(1), 59-63. https://jurnalfkip.unram.ac.id/index.php/JPPM/article/view/1013

Suliman, A. (2017). Mathematics Teachers' Perception of Using Social Media in Their Teaching in Tabuk, Saudi Arabia. IEJME-Mahematics Education, 12(2), 111-131.

Sumintono, B., \& Widhiarso, W. (2014). Aplikasi Model Rasch untuk Penelitian Ilmu-Ilmu Sosial. Trim Komunikata Publishing House.

Wolf, S., Magnuson, K. A., \& Kimbro, R. T. (2017). Family Poverty and Neighborhood Poverty: Links with Children's School Readiness Before and After The Great Recession. Children and Youth Services Review, 79(June), 368-384. https://doi.org/10.1016/j.childyouth.2017.06.040

Wopereis, I. G. J. H., Kirschner, P. A., Paas, F., Stoyanov, S., \& Hendriks, M. (2005). Failure and Success Factors of Educational ICT Projects: A Group Concept Mapping Approach. British Journal of Educational Technology, 36(4), 681-684.

Youssef, A. ben, \& Dahmani, M. (2008). The Impact of ICT on Student Performance in Higher 
Education: Direct Effects, Indirect Effects and Organisational Change. RUSC, 5(1), 4556. http://www.uoc.edu/rusc/5/1/dt/eng/benyoussef_dahmani.pdf 